\title{
New Records of Parasitoids Hymenopteran (Hymenoptera: Chalcidoidea) Associated With Maconellicoccus hirsutus (Hemiptera: Pseudococcidae) in the State of São Paulo
}

\author{
Matheus A. de Siqueira ${ }^{1}$, Ana Lúcia B. G. Peronti ${ }^{1}$, Nilza M. Martinelli ${ }^{1}$ \& Valmir A. Costa ${ }^{2}$ \\ ${ }^{1}$ Faculdade de Ciências Agrárias e Veterinárias, Universidade Estadual Paulista "Júlio de Mesquita Filho", \\ Jaboticabal, SP, Brazil \\ ${ }^{2}$ Centro Experimental do Instituto Biológico, Campinas, SP, Brazil \\ Correspondence: Matheus A. de Siqueira, Departamento de Fitossanidade, Faculdade de Ciências Agrárias e \\ Veterinárias, Universidade Estadual Paulista "Júlio de Mesquita Filho", Via de acesso Prof. Paulo Donato \\ Castellane, s/n, 14884-900, Jaboticabal, São Paulo, Brazil. Tel: 55-163-209-7311. E-mail: \\ matheuspucc2012@gmail.com
}

Received: December 19, 2018

Accepted: January 27, 2019 Online Published: March 15, 2019

doi:10.5539/jas.v11n4p100

URL: https://doi.org/10.5539/jas.v11n4p100

\begin{abstract}
Survey of hymenoptera parasitoids of pink-hibiscus-mealybug, Maconellicoccus hirsutus (Green, 1908) infesting Hibiscus rosa-sinensis was conducted in two municipalities of state of São Paulo, Brazil from August 2016 to August 2017. Nine species of chalcidoid wasps were obtained: Anagyrus kamali Moursi (1948); Anagyrus sp. aff. mirtesae Noyes and Menezes (2000); Anagyrus sp.; Bothriocraera bicolor Compere and Zinna (1955); Cheiloneurus sp., Gyranusoidea deionae Noyes (2000); Prochiloneurus sp. (Encyrtidae); Aprostocetus sp. (Eulophidae); and Chartocerus sp. (Signiphoridae). Anagyrus kamali and G. deionae were the most frequent species, corresponding to $67.26 \%$ and $22.62 \%$ of the parasitoids, respectively. Bothriocraera bicolor, Chartocerus and $G$. deionae are recorded for the first time associated with M. hirsutus. Gyranusoidea deionae and B. bicolor are recorded for the first time in Brazil. The seasonal study of M. hirsutus and its parasitoids was carried out in January to December 2017on 16 hibiscus plants, aligned in the hedge in the experimental area of the FCAV/UNESP in Jaboticabal, SP. For this purpose, ovisacs, nymphs and adults of mealybug were counting on infested plants and the adult parasitoids collected in Möerick traps. Maconellicoccus hirsutus was observed during the periods of January-March and October-December, with the highest infestation in January and February. In the traps, a total of 92 specimens of pink-mealybug parasitoids were obtained: $65 \%$ belonging to $A$. kamali and $35 \%$ to $G$. deionae.
\end{abstract}

Keywords: Hibiscus rosa-sinensis, tritrophic interactions, Encyrtidae

\section{Introduction}

The pink-hibiscus-mealybug (PHM), Maconellicoccus hirsutus (Green, 1908) (Hemiptera: Pseudococcidae), is a polyphagous species reported on more them 300 species of host plants, distributed in 78 families, mainly in the tropical and subtropical regions of the world (García Morales et al., 2018).

In Brazil, this mealybug was first reported in 2010, in Boa Vista, Roraima. Currently, it is spread across seven other states, of which Santa Catarina is the southernmost. Of the 32 species of host plants from 17 families reported in the country, stand out: cocoa, Theobroma cacao L.; cupuaçu, Theobroma grandiflorum (Willd. Ex Spreng) K. Schum; and okra, Abelmoschus esculentus L. Moench; (Malvaceae); sugar-apple, Annona squamosa L., and soursop, Annona muricata L.; (Anonnaceae), and teak, Tectona grandis L.f. (Lamiacea) (Culik et al., 2013, Marsaro-Junior et al., 2013, Alexandre et al., 2014; Broglio et al., 2015, Morais et al., 2015, Peronti et al., 2016; Peres-Filho, 2017, Ramos et al., 2018).

In São Paulo State, M. hirsutus was first recorded in 2012, in the municipality of São Carlos on H. rosa-sinensis (Morais et al., 2015). In the next year collected in other 11 municipalities infesting Erythrina spp. (Fabaceae), Ficus pumila L. (Moraceae), and Eugenia uniflora L. (Myrtaceae), but mainly on hibiscus species in urban areas; and some teak, Tectona grandis L.f. (Lamiales: Lamiaceae), cultivated in the northwest region of State (Peronti \& Martinelli, 2014). 
The management of $M$. hirsutus might be performed in different ways, including chemical control indicated mainly for high infestations in restricted environments, such as nursery planting, where infested plants do not resist the presence of the pest (Chong et al., 2015). However, the waxy cover, eggs inserted in a filamentous secretion (ovisac), and habit of nymphs and adult females to settle in cryptic parts of the host plant, protects them from contact with insecticidal sprays (Kairo et al., 2000).

Biological control has been extensively used for this species. Worldwide, 85 natural enemies have been reported that are associated with M. hirsutus, 39 are hymenopterous parasitoids (Hymenoptera: Encyrtidae) and 46 predators, predominantly distributed in the families of Coccinellidae (Coleoptera) and Chrysopidae (Neuroptera) (Chong et al., 2015, Peronti et al., 2016).

However, the complex of natural enemies associated with an insect pest can be variable between different zoogeographic regions or even in different parts of the same country, demonstrating the importance of regional surveys. Goolsby et al. (2002) found the predators Cryptolaemus montrouzieri Mulsant, 1853 (Coleoptera: Coccinellidae), Cacoxenus perspicax (Knab, 1914) (Diptera: Drosophilidae) and the parasitoid Gyranusoidea indica Shafee, Alam \& Agarwal, 1975 (Hymenoptera: Encyrtidae) in Queensland, northeastern Australia. While whereas in western Australia and the northern territory the researchers found the predator Mataeomera sp. (Lepidoptera: Erebidae); the parasitoids Coccophagus sp. (Hymenoptera: Aphelinidae) and Coccidoctonus sp. (Hymenoptera: Encyrtidae), all collected from M. hirsutus on a native Hibiscus species.

In Brazil, nine species of natural enemies are reported that are associated with PHM. The parasitoids G. indica and Anagyrus kamali Moursi, 1948 (Hymenoptera: Encyrtidae); and predators Cycloneda sanguinea (Linnaeus, 1763), C. montrouzieri, Chilocorus nigrita (Fabricius, 1798), Exoplectra sp., Harmonia axyridis (Pallas, 1773) and Tenuisvalvae notata (Mulsant, 1850) (Coleoptera: Coccinellidae) and Ceraeochrysa sp. (Neuroptera: Chrysopidae) (Marsaro-Júnior et al., 2013, Peronti et al., 2016).

A. kamali and G. indica are important in biological control programs of PHM, mainly in the South of North America and the Caribbean region (Kairo et al., 2000). In states of California, Florida, Hawaii (USA) and Mexico, biological control programs using these natural enemies were successfully achieved up to $95 \%$ reduction of M. hirsutus population (Roltsch et al., 2006).

In Roraima, northern Brazil Negrini et al. (2018) studied the population fluctuations of M. hirsutus and its natural enemies in a sugar-apple orchard, Annona squamosa L. (Anonnaceae) and verified highest infestation occurred in August and February-March and the average parasitism by A. kamali in fruits of the 50\%, with highest rates in periods of greatest infestation by M. hirsutus.

Therefore, the objective of this work was to increase the knowledge about the hymenopterous parasitoids associated to M. hirsutus in the state of São Paulo and study of the seasonality of M. hirsutus and its parasitoids on Hibiscus rosa-sinenses in an experimental area in the municipality of Jaboticabal, SP.

\section{Materials and Methods}

\subsection{Survey of Natural Enemies}

The branches, leaves and flowers of Hibiscus rosa-sinensis infested by M. hirsutus were collected in public and private gardens in the municipalites of Campinas, Jaboticabal and São Carlos, SP, Brazil and transported to the Laboratory of Biosystematics of Hemipteran (LABHEM) of the Plant Protection Department of the Universidade Estadual Paulista "Julio de Mesquita Filho"-Campus Jaboticabal, from August 2016 to August 2017. Sporadic samples were also obtained in Jales, Ribeirão Preto, São Paulo, Vinhedo and Votuporanga, SP.

The collected part of the specimens of M. hirsutus was stored in vials containing $70 \%$ alcohol for posterior montage and identification. Other parts were placed in glass tubes sealed with paper film under controlled conditions $\left(25 \pm 2{ }^{\circ} \mathrm{C}\right.$, photoperiod of 12 hours and UR $\left.65 \pm 5 \%\right)$ in BOD incubator for 25 days, according to methodology adapted from Prado et al. (2015). At each 48 hour intervals, the emerged parasitoids were transferred to $2 \mathrm{ml}$ eppendorf microtubes filled in $70 \%$ alcohol.

The mealybugs were slided-mounted following the methodology described by Granara de Willink (1990) and identified according morphological characteristics of the adult female as described by (Miller, 1999; Miller et al., 2011).

Most of hymenopterous parasitoids were prepared in double-mount (Hanson \& Gauld, 2006). Species smaller than $0.7 \mathrm{~mm}$ were mounted on permanent slides following the technique of Querino and Zucchi (2011). Subsequently, the parasitoids were identified under optical stereoscopic microscope at the genus or species level, according to the following works: Fernández and Sharkey (2006) and Hanson and Gauld (2006) for 
identification of families of Chalcidoidea; for genera of Encyrtidae, Noyes (1980); for Eulophidae, Schauff et al., (1997); and for Signiphoridae Rao (1974). The determination of the species was used: Noyes (2000) and Noyes and Hayat (1994).

Specimens "voucher" were deposited in the following institutions: Reference Collection of Insects and Mites (CRIA) of the Department of Plant Protection of FCAV/UNESP-Jaboticabal/SP; and Collection "Oscar Monte" of Entomophagous Insects (IB-CBE) of the Biological Institute, Campinas, SP, for future consultations.

\subsection{Seasonality of M. hirsutus and Its Parasitoids}

The samples were carried out on a hedge of Hibiscus rosa-sinensis L. (Malvaceae), with 16 plants, in an open environment in the experimental area of the Plant Protection Department of FCAV/UNESP, between January and December 2017. Monthly, nymphs and adults of mealybug were collected from an apical branch of each plant.

In the same period, parasitoid hymenoptera were obtained from Möericke traps arranged close to the hibiscus plants and kept for two days. The mealybugs and parasitoids previously filled in $70 \%$ alcohol were triaged and counted under optical stereomicroscope; and subsequently mounted on entomological pin or permanent slides, for identification.

\section{Results}

\subsection{Survey of Natural Enemies}

A total of 168 specimens of parasitoid hymenoptera (Hymenoptera: Chalcidoidea) were obtained from $M$. hirsutus, distributed in nine species: 7 encyrtidae, 1 Eulophidae and 1 Signiphoridae (Table 1). Bothriocraera bicolor, Chartocerus and G. deionae are registered for the first time associated with this pseudococcid. Gyranusoidea deionae are recorded for the first time in Brazil; and Bothriocraera bicolor be the first record for the state of São Paulo (Figure 1).

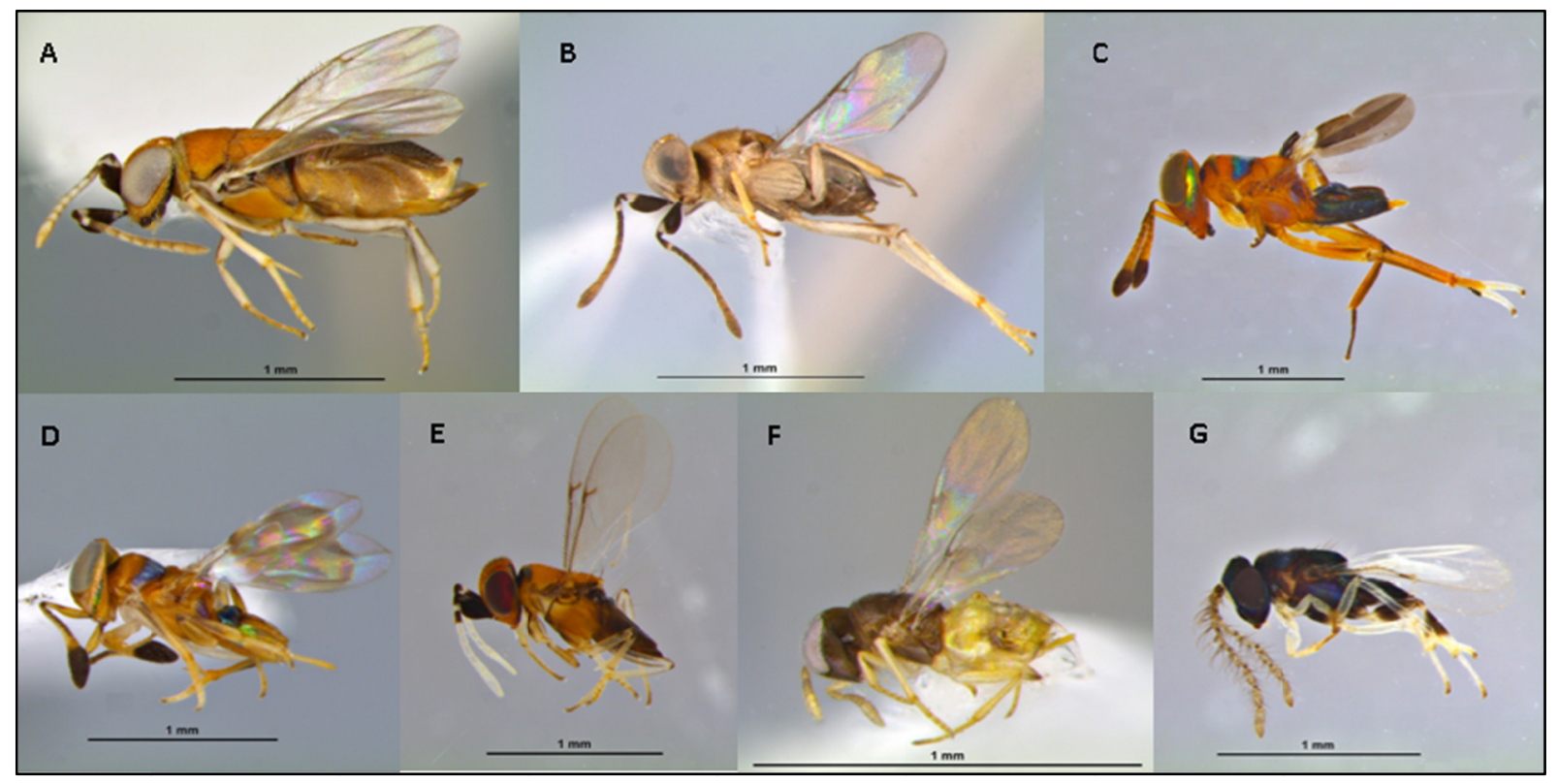

Figure 1. Parasitoids associated with Maconellicoccus hirsutus in Hibiscus-rosa-sinensis in the state of São Paulo: (A) Anagyrus kamali; (B) Gyranusoidea deionae; (C) Cheiloneurus sp.; (D) Prochiloneurus sp.; (E) Anagyrus sp. aff. mirtesae; (F) Bothriocraera sp.; (G) Anagyrus sp. Fotos: (A, E, F) Costa V.A.; (B, C. D.G) Siqueira, M.A.

Encyrtidae presented the highest number of specimens obtained from M. hirsutus, corresponding to $98.80 \%$ of the total. A. kamali and G. deionae were the most frequent species, with $67.26 \%$ and $22.62 \%$, respectively. Sporadic species with a small number of emerged specimens not exceeding $2 \%$ of the total (Table 1 ). 
Table 1. Parasitoids associated with Maconellicoccus hirsutus (Hemiptera: Pseudococcidae) collected on Hibiscus sp. in the state of São Paulo between August 2016 and August 2017. Number and percentage obtained by species

\begin{tabular}{ll}
\hline Parasitoids & Number of individuals and percentage (\%) \\
\hline Encyrtidae & $113(67.26 \%)$ \\
Anagyrus kamali Moursi, 1948 & $3(1.79 \%)$ \\
Anagyrus sp. aff. mirtesae Noyes \& Menezes, 2000 & $4(2.38 \%)$ \\
Anagyrus sp. & $5(2.98 \%)$ \\
Bothriocraera bicolor Compere \& Zinna, 1955 & $2(1.19 \%)$ \\
Cheiloneurus sp. & $38(22.62 \%)$ \\
$* *$ Gyranusoidea deionae Noyes, 2000 & $1(0.60 \%)$ \\
$*$ Prochiloneurus sp. & $1(0.60 \%)$ \\
\hline Eulophidae & $1(0.60 \%)$ \\
Aprostocetus sp. & \\
\hline Signiphoridae & \\
$*$ *Chartocerus sp. &
\end{tabular}

Note. * Species associated for the first time with Maconellicoccus hirsutus; ${ }^{* *}$ Species recorded for the first time in Brazil.

\subsection{Seasonality of M. hirsutus and Its Parasitoids}

The pink-hibiscus-mealybug was observed in the periods of January-March and October-December, with the highest infestation in the months of January and February, reaching the average of 12 adults and 63 nymphs by evaluated branch (Figure 2). From April to September PHM was not observed, probably due to the lower temperatures. The number of nymphs was greater than the number of ovisacs and adults obtained during all experiments.

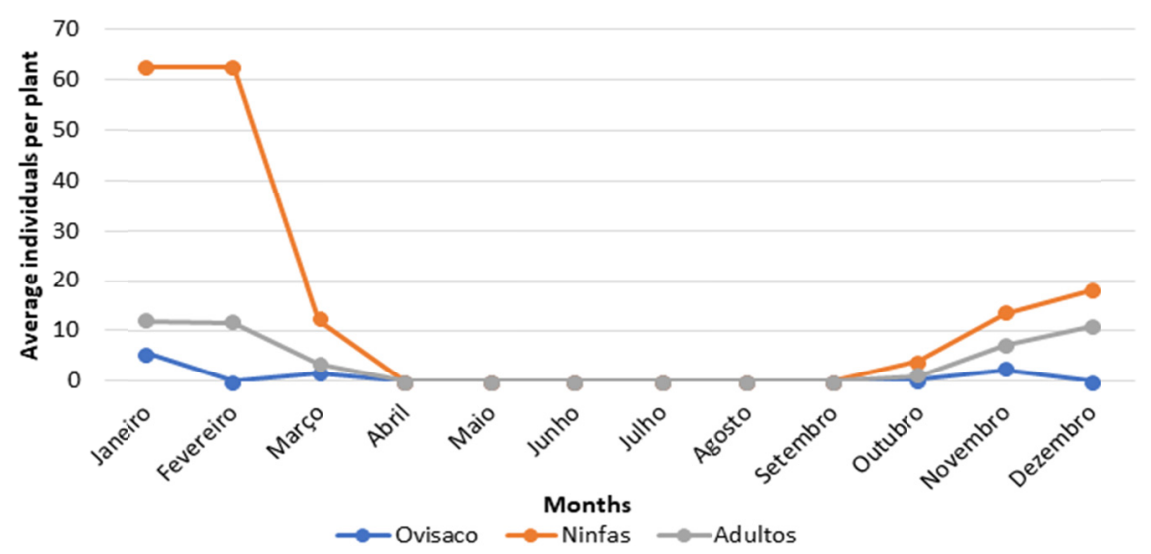

Figure 2. Seasonality of Maconellicoccus hirsutus (Hemiptera: Pseudococcidae) collected in Hibiscus sp. in the state of São Paulo between January 2017 and December 2017. Average individuals per plant

In the traps, a total of 92 specimens of hymenopterous known to parasite PHM were obtained within the 12 months of sampling: $65 \%$ of A. kamali and 35\% of Gyranusoidea deionae (Hymenoptera: Encyrtidae). Both species had higher incidence in the month of February, coinciding with the final period of high infestation of the mealybug; and, in November, period in which the pest population was re-established. Only 14 specimens of parasitoids were obtained between March and September, with a reduction in the populations of M. hirsutus. (Figure 3). 


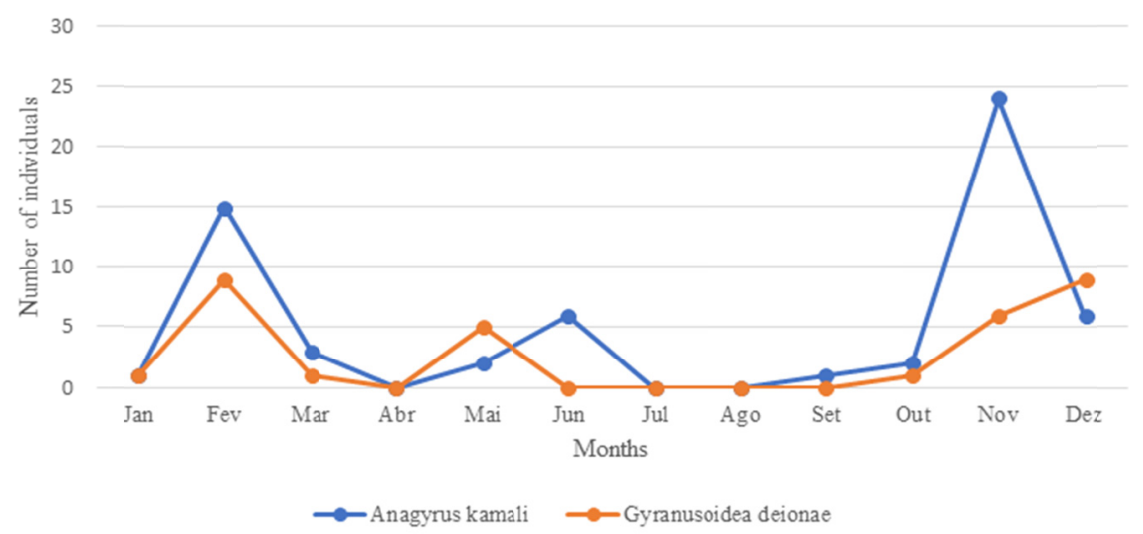

Figure 3. Number of Anagyrus kamali and Gyranusoidea deionae collected with Morieck traps in Hibiscus sp. in the state of São Paulo between January 2017 and December 2017

\section{Discussion}

\subsection{Encyrtidae}

Encyrtidae has the most parasitoids used for biological control of species of Hemiptera. Coccidae and Pseudococcidae (Hemiptera: Coccomorpha), corresponding to more than $60 \%$ of the already registered hosts (Noyes \& Hayat, 1994; Noyes et al., 1997). Noyes and Hayat (1994) summarized information about Encyrtidae imports to biological control programs in all the world since 1992, accounting 94 species in 382 introductions; with a success rate about 90\% (Noyes et al., 1997). Anagyrus aegyptiacus Moursi, 1948, Anagyrus dactylopii (Howard, 1898), A. kamali and Anagyrus pseudococci (Girault, 1915) have applied to control of pseudococcids (Mani \& Shivaraju, 2016).

Anagyrus spp. is frequently reported in the parasitoid complex associated with species of several genus of Pseudococcidae, (Noyes, 1994). Anagyrus Howard has about 280 species around the world, of which nine exist in Brazil (Noyes, 2018). In Brazil, the encyrtids Anagyrus diversicornis (Howard, 1894) and Aenasius vexans Kerrich, 1967 were imported from Colombia and Venezuela, respectively, for the control of mealybug, Phenacoccus herreni Cox and Williams (1981), pest of cassava in the northeastern region of Brazil (Bento, 2002).

Anagyrus kamali is solitary endoparasitoid (Pollard, 1995). From Asian (Williams, 1986) this species currently occurs in 23 countries around the world (Noyes, 2018). It was widely used for the biological control of $M$. hirsutus in USA (California and Florida), Egypt, Mexico, India, Hawaii and Caribbean Islands (Kairo, 2000; Roltsch et al., 2006). The first imported specimens were obtained from China, California and Florida (Chong, 2009). Several other pseudococcids of economic importance such as, striped-mealybug Ferrisia virgata (Cockerell, 1893), cotton-mealybug Phenacoccus solenopsis Tinsley 1898, and root-mealybug Planococcus citri (Risso, 1813) are frequently associated with this encyrtid (Sagarra et al., 2001a; Gregory et al., 2012).

Anagyrus mirtesae, is known to Costa Rica (Noyes, 2000) and Mexico (Sánchez-García, 2016), with uncertain origin (Noyes, 2000). The information related to this parasitoid is scarce, having only the description of females (Noyes, 2000). It resembles Anagyrus cepio Noyes, 2000 and Anagyrus remotor Noyes, 2000. The three species are differentiated by the coloration of the flagellum. In A. mirtesae, only the first flagellum has coloration dark brown; A. remotor the brown coloration is present in the first and third flagellum; and A. cepio shows all flagellum segments dark brown (Noyes, 2000).

Bothriocraera bicolor, with uncertain origin, is known only to the Neartic and African regions (Noyes, 2018). This species has already been used in several regions of the city of Trinidad in California, USA. It was also introduced in Ghana and occidental Africa for the biological control of mealybugs Ferrisia virgata, Planococcus citri and Pseudococcus longispinus on citrus and cacao crops (Trjapitzin et al., 2004).

Cheiloneurus Westwood, 1833 has 150 species distributed around the world. In Brazil, the following are known: Cheiloneurus inimicus Compere, 1925, Cheiloneurus kuisebi Prinsloo, 1985, Cheiloneurus nigrescens Howard, 1897 (Noyes, 2018; De Santis \& Fidalgo, 1994; De Santis, 1972). Species of this genus, in general are reported with secondary parasitoids of coccids (Noyes, 2018; Noyes \& Hayat, 1984). 
Gyranusoidea deione is a Neotropical species of uncertain origin, registered only in Costa Rica (Noyes, 2000). It is very similar to $G$. indica, differing mainly in having an intense dark spot that connects the torulus and eye, the mid coxa is concolorous with the hind coxa, in addition to the length of the gonostylus $0.25 \mathrm{x}$ as long as the ovipositor. In $G$. indica the spot between the torulus and the eyes is conspicuous and dark brown; the hind coxae is pale yellow contrasting with brown mid coxa; and the length of the gonostylus $0.25 \mathrm{x}$ as less as the ovipositor (Noyes, 2000).

Prochiloneurus Silvestri 1915, is a genus composed of 29 species in the world (Noyes, 2018). In Brazil, for example, only Prochiloneurus dactylopii (Howard, 1885) was registered (Löhr et al., 1990; Noyes, 2018). They are known mainly as secondary parasitoids of Coccidae, Pseudococcidae and Coccinellidae (Noyes \& Hayat, 1984; Hayat, 2006).

\subsection{Eulophidae}

Eulophidae are parasitoids of a great diversity of arthropods, being found parasitizing from arachnids, nematodes and distinct species of insects during various stages of development (La Salle, 1994). There are few associations between eulophids with mealybugs. Most species have been associated as primary or secondary parasitoids of coccids and other 41 families of arthropods (La Salle, 1994; Peck, 1963).

Aprostocetus Westwood, 1833 is a very complex genus, with more than 800 species registered around the world (La Salle, 1994). Aprostocetus minutus (Howard, 1881) is the species with the highest number of hosts belonging to the family Pseudococcidae, being associated with six genera in the world (La Salle, 2006; Noyes, 2018). The species reported in Brazil are not associated with this family of scale insects, representing 15 species in the country, but the genus Aprostocetus has already been cited in the literature associated with Pseudococcidae in Brazil (Lopes et al., 2017; Chong et al., 2015).

\subsection{Signiphoridae}

Signiphoridae is one of the smallest families of Chalcidoidea, with four genera and 84 species in the world (Hayat, 2004). In Brazil, 16 species were registered, 15 of the genus Signiphora (Noyes, 2018), of wich four were associated with species of mealybugs, Chartocerus niger (Ashmead, 1900), Signiphora bifasciata Ashmead, 1900, Signiphora fax Girauld, 1913 and Signiphora hyalinipennis Girauld, 1913 (Löhr et al., 1990).

Chartocerus Motschulsky, 1859, is mostly hyperparasitoids of species of Hymenoptera, presenting preference for other Chalcidoidea (Woolley 1988). This genus is cosmopolitan, with 33 species described around the world (Noyes 2018). In Brazil only, Chartocerus niger was associated with Planococcus citri (Risso, 1813) (Ashmead, 1900) (De Santis, 1979).

\subsection{General Discussion}

Nine species of hymenopterous parasitoids were recorded to be associated with M. hirsutus in the state of São Paulo distributed into seven genera. According to the literature, species of Anagyrus, Gyranusoidea, Bothriocraera have been mentioned preferentially as primary parasitoids of mealybugs and those of the genera Chartocerus sp., Cheiloneurus sp. and Prochiloneurus sp. as secondary parasitoids. Species of the genus Aprostocetus have been related as primary and secondary parasitoids (Table 2). 
Table 2. Species by family, associations and literature pertinent to their hosts. ${ }^{*}$ numbers in parentheses are corresponding to the number of host families of the parasitoid

\begin{tabular}{|c|c|c|c|}
\hline Family & Species & Category of parasitism and hosts & Reference \\
\hline \multirow[t]{7}{*}{ Encyrtidae } & Anagyrus kamali & Primary parasite of Pseudococcidae nymphs & $\begin{array}{l}\text { Noyes, 1994; Moursi, 1948; Miller, } \\
1999 .\end{array}$ \\
\hline & Anagyrus sp. aff. mirtesae & Unknown & Noyes, 2000; Sánchez-García, 2016. \\
\hline & Anagyrus sp. & Primary parasite of Pseudococcidae nymphs & Kerrich, 1982, Noyes, 1994. \\
\hline & Bothriocraera bicolor & Primary parasite of Pseudococcidae nymphs & Bartlett, 1958; Compere, 1955; \\
\hline & Cheiloneurus sp. & $\begin{array}{l}\text { Hyperparasitoids of Chalcidoidea (Encyrtidae and } \\
\text { Aphelinidae). }\end{array}$ & $\begin{array}{l}\text { Herting, 1972; Japoshvili \& Celik, } \\
2010 .\end{array}$ \\
\hline & Gyranusoidea deionae & Unknown & Noyes, 2000. \\
\hline & Prochiloneurus & $\begin{array}{l}\text { Hyperparasitoids of Hemiptera (Coccidae, } \\
\text { Pseudococcidae and Coccinelidae) and primary } \\
\text { parasitoid of Chalcidoidea (Encyrtidae). }\end{array}$ & $\begin{array}{l}\text { Noyes, 1984; Prinsloo, 1983; } \\
\text { Triapitsyn, 2014. }\end{array}$ \\
\hline Eulophidae & Aprostocetus & $\begin{array}{l}\text { Primary parasite of } 43 \text { families of the phylum } \\
\text { Arthropoda - Díptera (6), Coleoptera (4), Hemiptera } \\
\text { (9), Lepidoptera (16), Orthoptera (1) and Orthoptera } \\
\text { (2); and Hyperparasitoid of Diptera (2) and } \\
\text { Hymenoptera (5)*. }\end{array}$ & La Salle, 1994; Noyes, 2018. \\
\hline Signiphoridae & Chartocerus & $\begin{array}{l}\text { Hyperparasitoid of Diptera (Drosophilidae), Hemiptera } \\
\text { (Diaspididae, Pseudococcidae and Psyllidae) and } \\
\text { Lepidoptera (Gracillariidae), and primary parasitoid of } \\
\text { Chalcidoidea (Encyrtidae and Eulophidae). }\end{array}$ & $\begin{array}{l}\text { Simmonds, 1957; } \quad \text { Mani, } \\
\text { Thontadarya \& Singh, 1987; }\end{array}$ \\
\hline
\end{tabular}

Anagyrus was the genus with the largest number of specimens, A. kamali, A. sp. aff. mirtesae and Anagyrus sp.; Species of this genus are known for their high specificity to mealybugs. Of the nine registered hosts for $A$. kamali, eight are from pseudococcids (Noyes, 2018). This exotic hymenopteran was probably introduced in Brazil together with the pink-hibiscus-mealybug, both recorded for this country in the same year, in Boa Vista, Roraima (Marsaro-Junior et al., 2013). For A. mirtesae, previously known to Costa Rica and Mexico, no host has been known until now (Noyes, 2000; Sánchez-García, 2016).

Several studies related to the biology of $A$. kamali were carried out and verified the great potential of the species for the biological control of M. hirsutus (Sagarra et al., 2000a; Sagarra et al., 2000b; Sagarra et al., 2001a; Sagarra et al., 2001b; Persad \& Khan, 2002; Serrano \& Lapointe, 2002; Persad \& Khan, 2007; Montes-Rodríguez, 2012). Anagyrus kamali, preferably feeds from adult female of PHM, but it can also parasitize all the nymphal instars (Sagarra \& Peterkin, 1999).

For Gyranusoidea deionae, the second species with the largest number of specimens was reported as a first host of it in this study. This species is extremely similar to G. indica which as obtained from M. hirsutus by Peronti et al. (2016) in the state of São Paulo. However, it was not found during this survey. Due to the great similarity of them morphometric and molecular studies would be required to verify the status and distribution of both.

For the Neotropical region, 19 species of parasitoids had previously been associated with M. hirsutus (Chong et al., 2015; Culik et al., 2013). Adding the four species here reported for the first time to this region, 23 species are now known. In general, Anagyrus and Gyranusoidea include species better distributed in the Australian and Oriental regions, except for a few species such as Anagyrus sp. aff. mirtesae and G. deionae, which are only registered in Costa Rica, Mexico and Brazil.

The number of species of hymenopterous parasitoids associated with mealybugs has been increased in recent years, however the records, have been done to isolated species. Studies that include surveys of species in a given region are less frequent (Chong et al., 2015; Culik, et al., 2013; Mani et al., 1987). Surveys of hymenopterous parasitoids associated with M. hirsutus were conducted in India by Mani et al. (1987) and Michaud \& Evans, (2018) in Puerto Rico. In India: A. dactylopii, Anagyrus mirzai Agarwal and Alam, 1959 (= Gyranusoidea mirzai) and Alamella flava Agarwal, 1966 (Encyrtidae), Allotropa sp. Near A. japonica Ashmead, 1904 (Platygastridae), Leptopilina sp. (Figitidae) and Chartocerus sp. Near C. walkeri Hayat, 1970, (Signiphoridae) were reported and in Puerto Rico, A. kamali, G. indica, Acerophagus nubilipennis Dozier, 1926, C. inimicus and A. minutus. Of the six species obtained in India, two are included in common genera to those found in this study, Anagyrus spp. and 
Chartocerus sp. Four of the five species associated with PHM in Puerto Rico belong to genres common to those species found in this study with $\mathrm{A}$. kamali representing $70 \%$ of the number of parasitoids obtained.

In the municipality of Jaboticabal-SP, the population peaks of M. hirsutus in the years 2016-2017 occurred in January and February, where temperatures were higher. These results corroborate with those obtained by Negrini et al. (2018), demonstrating that in the months of May-July there is no presence of mealybug in the field, but in the months that followed, in the periods of spring and summer, February and end of September, respectively, the greater amount of mealybugs occur and their re-establishment in the field, also resulted in the appearance of the natural enemies.

Negrini et al. (2018) evaluated the number of M. hirsutus mummies, corresponding to parasitized mealybugs, in A. squamosa fruits. The highest pupal average was obtained in September, February and March, being the period corresponding to the highest population peaks of PHM, all of A. kamali. In the present study, hymenopteran parasitoid species were collected from Möericke traps and two species known to parasite PHM were captured ( $A$. kamali and G. deionae). The seasonality of A. kamali in relation to population peaks of M. hirsutus was similar in both studies.

This survey contributed to report new species of natural enemies associated with M. hirsutus in the world and in Brazil particularly in addition, the study demonstrated that this exotic pest is being naturally controlled in the state of São Paulo by a complex of hymenoptera parasitoids especially A. kamali corresponding to more than $65 \%$ of the parasitoids obtained by manual collection of parasitized mealybugs and traps.

\section{References}

Arruda Pinto, R. S. D. (2002). Indicadores de desempenho de frota de empresas agroindustriais canavieiras brasileiras (Master's thesis, Escola Superior de Agricultura "Luiz de Queiroz", Universidade de São Paulo).

Alexandre, F., Souza, G. P., Ebel, J., Vieira, R. D. A., \& Krueger, R. (2014). Detection of pest Maconellicoccus hirsutus Green (pink hibiscus cochineal) in urban hibiscus and ornamental crops in Santa Catarina (p. 1). Brazilian Congress of Entomology, No. 25. Goiania: SEB.

Bento, J. M. S., Moraes, G. J., Matos, A. P., Warumby, J. F., \& Bellotti, A. C. (2002). Biological control of cassava mealybug in Northeast Brazil. In J. R. P. Parra, P. S. M. Botelho, B. S. Corrêa-Ferreira, \& J. M. S. Bento (Eds.). Biological control in Brazil: Parasitoids and predators (pp. 395-408). Manole, São Paulo, SP, Brazil.

Broglio, S. M. F., Cordero, E. P., Santos, J. M., \& Micheletti, L. B. (2015). Record of Pink-mealybug-hibiscus infesting fruit in Maceió, Alagoas, Brazil. Revista Caatinga, 28(2), 242-248.

Culik, M. P., Fornazier, M. J., Martins, D. D., Zanuncio, J. S., Ventura, J. A., Peronti, A. L. B. G., \& Zanuncio, J. C. (2013). The invasive mealybug Maconellicoccus hirsutus: Lessons for its current range expansion in South America and invasive pest management in general. Journal of Pest Science, 86, 387-398. https://doi.org/10.1007/s10340-013-0512-z

Chong, J. H. (2009). First report of the pink hibiscus mealybug, Maconellicoccus hirsutus (Green) (Hemiptera: Pseudococcidae), in South Carolina. Journal of Agricultural and Urban Entomology, 26(2), 87-94. https://doi.org/10.3954/1523-5475-26.2.87

Chong, J. H., Aristizábal, L. F., \& Arthurs, S. P. (2015). Biology and management of Maconellicoccus hirsutus (Hemiptera: Pseudococcidae) on ornamental plants. Journal of Integrated Pest Management, 6(1). https://doi.org/10.1093/jipm/pmv004

Compere, H., \& Zinna, G. (1955) Tre nuovi generi e cinque nuove especie di Encyrtidae. Bollettino del Laboratorio di Entomologia Agraria 'Filippo Silvestri, 14, 101.

Herting, B. (1972) Homoptera: A catalogue of parasites and predators of terrestrial arthropods. Section A. Host or Prey/Enemy Slough (p. 123). England: Commonwealth Agricultural Bureaux.

De Santis L. (1972). Additions to the Argentine wildlife of encírtidos. III. (Hymenoptera: Chalcidoidea). Rev Peruana Entomol Agr, 8.

De Santis L. (1979). Catalog of the calcidoideos himénopteros of America to the south of the United States. Publicación Especial Comisión de Investigaciones Cientificas Provincia de Buenos Aires (p. 250).

De Santis, L., Fidalgo P. (1994). Catalog of Calcidoideos Hymenoptera. Serie de la Academia Nacional de Agronomia y Veterinaria, 13, 73. 
Fernández, F., \& Sharkey, M. J. (2006). Introduction to the Hymenoptera of the Neotropical Region (p. 893). Bogotá: Sociedad Colombiana de Entomología y Universidad Nacional de Colombia.

García, M. M., Denno, B. D., Miller, D. R., Miller, G. L., Ben-Dov, \& Hardy, N. B. (2018). ScaleNet: A literature-based model of scale insect biology and systematics. Retrieved from http://scalenet.info/fams/ Pseudococcidae

Goolsby, J. A., Kirk, A. A., \& Meyerdirk, D. E. (2002). Seasonal phenology and natural enemies of Maconellicoccus hirsutus (Hemiptera: Pseudococcidae) in Australia. Florida Entomologist, 85(3), 494-498. https://doi.org/10.1653/0015-4040(2002)085[0494:SPANEO]2.0.CO;2

Granara de Willink, M. C. (1990). Conociendo nuestra fauna I. Superfamilia Coccoidea (Homoptera: Sternorhyncha). Serie Monográfica y Didáctica (p. 43). Facultad de Ciencias Nauturales e Instituto Miguel Lillo, Universidad Nacional de Tucumán.

Gregory, E., Kondo, T., Maya-Álvarez, M. F., Hoyos-Carvajal, L. M., Quiroz, J. A., \& Silva-Gómez, M. (2012). First report of Anagyrus kamali Moursi and Gyranusoidea indica Shafee, Alam and Agarwal (Hymenoptera: Encyrtidae), parasitoids of the pink hibiscus mealybug Maconellicoccus hirsutus (Green) (Hemiptera: Pseudococcidae), on San Andres Island, Colombia. Corpoica Ciencia y Tecnología Agropecuária, 13(2), 219-222.

Hanson, P. E., \& Gauld, I. D. (2006). Hymenoptera of the Neotropical Region. Memoirs of the American Entomological Institute, 77, 1-994.

Hayat, M. (2004). A new species of Chartocerus (Hymenoptera: Chalcidoidea: Signiphoridae) from West Bengal, India. Zoos' Print Journal, 19, 1383-1385. https://doi.org/10.11609/JoTT.ZPJ.19.3.1383-5

Hayat, M. (2006). Indian Encyrtidae (Hymenoptera: Chalcidoidea) (p. 194). Aligarh, India: Aligarh Muslim Univ.

Japoshvili, G., \& Celik, H. (2010). Fauna of Encyrtidae, parasitoids of coccids in Golcuk Natural Park. Entomologia Hellenica, 19(2), 132-136. https://doi.org/10.12681/eh.11580

Kairo, M. T. K., Pollard, G. V., Peterkin, D. D., \& Lopez, V. F. (2000). Biological control of the hibiscus mealybug, Maconellicoccus hirsutus in the Caribbean. Integrated Pest Management Reviews, 5, 41-254. https://doi.org/10.1023/A:1012997619132

Kerrich, G. J. (1982). Further systematic studies on tetracnemine Encyrtidae (Hym.: Chalcidoidea) including a revision of the genus Apoanagyrus Compere. Journal of Natural History, 16, 399-430. https://doi.org/ $10.1080 / 00222938200770331$

LaSalle, J., \& Huang, D. W. (1994). Two new Eulophidae (Hymenoptera: Chalcidoidea) of economic importance from China. Bulletin of Entomological Research, 84, 51-56. https://doi.org/10.1017/S0007485300032223

LaSalle, J., Schauff, M. E., \& Hansson, C. (2006). Familia Eulophidae. In P. E. Hanson, \& I. D. Gauld (Eds.), Hymenoptera de la Region Neotropical, 77, 356-373.

Löhr, B., Varela, A. M., \& Santos, B. (1990). Exploration for natural enemies of the cassava mealybug, Phenacoccus manihoti (Homoptera: Pseudococcidae), in South America for the biological control of this introduced pest in Africa. Bulletin of Entomological Research, 80(4), 417-425. https://doi.org/10.1017/ S0007485300050677

Lopes, F. S. C. (2017). Bioprospecting, identification and management of mealybugs (Hemiptera: Pseudococcidae) and associated insects in vine agroecosystems in the Submedia of the São Francisco valley (p. 150, PhD. Thesis, Rural Federal University of Pernambuco, Pernanbuco, Brazil).

Mani, M., Thontadarya, T. S., \& Singh, S. P. (1987). Record of natural enemies on the grape mealybug, Maconellicoccus hirsutus (Green). Current Science, 56(12), 624-625.

Mani, M., \& Shivaraju, C. (2016). Mealybugs and their management in agricultural and horticultural crops (p. 647). New Delhi: Springer. https://doi.org/10.1007/978-81-322-2677-2

Marsaro-Júnior, A. L., Peronti, A. L. B. G., Penteado-Dias, A. M., Morais, E. G. F., \& Pereira, P. R. V. S. (2013). First report of Maconellicoccus hirsutus (Green, 1908) (Hemiptera: Coccoidea: Pseudococcidae) and the associated parasitoid Anagyrus kamali Moursi, 1948 (Hymenoptera: Encyrtidae), in Brazil. Brazilian Journal of Biology, 73(2), 413-418. 
Michaud, J. P., \& Evans, G. A. (2000). Current status of pink hibiscus mealybug in Puerto Rico including a key to parasitoid species. The Florida Entomologist, 83(1), 97-101. https://doi.org/10.2307/3496235

Miller, D. R. (1999). Identification of the Pink Hibiscus Mealybug, Maconellicoccus hirsutus (Green) (Hemiptera: Sternorrhyncha: Pseudococcidae). Insecta Mundi, 13(3-4), 189-203.

Miller, D. R., Rung, A., Venable, G. L., \& Gill, R. J. (2011). Scale insects: Identification tools for species of quarantine importance. Scale Families. ARS \& APHIS, USDA. Retrieved November 10, 2011, from http://www.sel.barc.usda.gov/ScaleKeys/ScaleInsectsHome/ScaleInsectsFamilies.html

Montes-rodríguez, J. M. (2012). First record of parasitoids of the pink-mealybug-hibiscus, Maconellicoccus hirsutus (Hemiptera: Pseudococcidae), in Colombia. Revista Colombiana de Entomología, 38(2), 274-275.

Morais, E. G. F., Peronti, A. L. B. G., Marsaro-Júnior, A. L., \& Amaro, G. C. (2015). Pink-mealybug, Maconellicoccus hirsutus (Green). In E. F. Vilela, \& R. A. Zucchi (Eds.), Pests introduced in Brazil: Insects and mites (pp. 21-24). Piracicaba: FEALQ.

Negrini, M., Morais, E. G., Batista, J. S., \& Chagas, E. A. (2018). Population fluctuations in the pink hibiscus mealybug and its natural enemies in Annona squamosa (Annonaceae) in Roraima, Brazil. Acta Amazonica, 48(1), 28-31. https://doi.org/10.1590/1809-4392201701131

Noyes, J. S. (2018). Universal Chalcidoidea Database. Retrieved January 30, 2018, from http://www.nhm.ac.uk/ our-science/data/chalcidoids/database

Noyes, J. S. (1980). A review of the genera of Neotropical Encyrtidae (Hymenoptera: Chalcidoidea). Bulletin of the British Museum (Natural History), 41, 107-253.

Noyes, J. S., \& Hayat, M. (1984). A review of the genera of Indo-Pacific Encyrtidae (Hymenoptera: Chalcidoidea). Bulletin of the British Museum, 48(3), 131-395.

Noyes, J. S., Hayat, M. (1994). Oriental mealybug parasitoids of the Anagyrini (Hymenoptera: Encyrtidae) (p. 560). CAB International, Oxon, UK.

Noyes, J. S., Woolley, J. B., \& Zolnerowich, G. (1997). Encyrtidae. In G. A. P. Gibson, J. T. Huber, \& J. B. Woolley (Eds.), Annotated keys to the genera of Nearctic Chalcidoidea (Hymenoptera) (pp. 170-320). NRC Research Press, Ottawa, Canada.

Noyes, J. S. (2000). Encyrtidae of Costa Rica (Hymenoptera: Chalcidoidea), 1. The subfamily Tetracneminae, parasitoids of mealybugs (Homoptera: Pseudococcidae). Memoirs of the American Entomological Institute, 62(36), 95-97.

Peck, O. (1963). A catalogue of the Nearctic Chalcidoidea (Insecta; Hymenoptera). Canadian Entomologist (Supplement), 30, 141. https://doi.org/10.4039/entm9530fv

Peres-Filho, O., Ben-Dov, Y., Wolff, V. R. D. S., Dorval, A., \& Souza, M. D. D. (2017). Maconellicoccus hirsutus (Green) Register in Teak Forest Santds in the Mato Grosso State, Brazil. Floresta e Ambiente, 24, 1-3. https://doi.org/10.1590/2179-8087.015715

Peronti, A. L. B. G., Martinelli, N. M., Alexandrino, J. G., Marsaro-Júnior, A. L., Penteado-Dias, A. M., \& Almeida, L. M. (2016) Natural enemies associated with Maconellicoccus hirsutus (Hemiptera: Pseudococcidae) in the state of São Paulo, Brazil. Florida Entomologist, 99(1), 21-25. https://doi.org/10.1653/024.099.0105

Persad, A., \& Khan, A. (2002). Comparison of life table parameters for Maconellicoccus hirsutus, Anagyrus kamali, Cryptolaemus montrouzieri and Scymnus coccivora. BioControl, 47(2), 137-149. https://doi.org/ 10.1023/A:1014581616965

Persad, A., \& Khan, A. (2007). Effects of four host plants on biological parameters of Maconellicoccus hirsutus Green (Homoptera: Pseudococcidae) and efficacy of Anagyrus kamali Moursi (Hymenoptera: Encyrtidae). Journal of Plant Protection Research, 47(1), 36-42.

Pollard, G. V. (1995). Pink or Hibiscus Mealybug in the Caribbean. Caraphin News, 12, 1-2.

Prado, E., Alvarenga, T. M., \& Santa-Cecília, L. V. C. (2015). Parasitoids associated with the black scale Saissetia oleae (Olivier) (Hemiptera: Coccidae) in olive trees in Minas Gerais State, Brazil. Acta Scientiarum. Agronomy, 37(4), 411-416. https://doi.org/10.4025/actasciagron.v37i4.19743

Prinsloo, G. L. A. (1983). Parasitoid-host index of Afrotropical Encyrtidae (Hymenoptera: Chalcidoidea) (Vol. 60, pp. 1-37). Department of Agriculture, South Africa. 
Querino, R. B., \& Zucchi, R. A. (2011). Trichogramma Identification Guide for Brazil (p. 103). Embrapa Information Technology, Brasília.

Rao, B. S. (1974). The genera of Signiphoridae (Hymenoptera) with description of a new genus. Bulletin of Entomological Research, 64(4), 525-531. https://doi.org/10.1017/S0007485300035835

Ramos, A. S. J. C., Costa, V. A., Peronti, A. L. B. G., \& Lemos, R. N. S. (2018). Hymenopteran parasitoids associated with scale insects (Hemiptera: Coccoidea) in tropical fruit trees in the eastern Amazon, Brazil. Florida Entomologist, 101, 273-278. https://doi.org/10.1653/024.101.0219

Roltsch, W. J., Meyerdirk, D. E., Warkentin, R., Andress, E. R., \& Carrera, K. (2006). Classical biological control of the pink hibiscos mealybug, Maconellicoccus hirsutus (Green), in southern California. Biological Control, 37, 155-166. https://doi.org/10.1016/j.biocontrol.2006.01.006

Sagarra, L. A., Vincent, C., \& Stewart, R. K. (2001a). Suitability of nine mealybug species (Homoptera: Pseudococcidae) as hosts for the parasitoid Anagyrus kamali (Hymenoptera: Encyrtidae). Florida Entomologist, 84(1), 112-116. https://doi.org/10.2307/3496669

Sagarra, L. A., Vincent, C., \& Stewart, R. K. (2001b). Body size as an indicator of parasitoid quality in male and female Anagyrus kamali (Hymenoptera: Encyrtidae). Bulletin of Entomological Research, 91(5), 363-367. https://doi.org/10.1079/BER2001121

Sagarra, L. A., \& Peterkin, D. D. (1999). Invasion of the Caribbean by the hibiscus mealybug, Maconellicoccus hirsutus Green (Homoptera: Pseudococcidae). Phytoprotection, 80(2), 103-113. https://doi.org/10.7202/ 706185ar

Sagarra, L. A., Vincent, C., \& Stewart, R. K. (2000a). Mutual interference among female Anagyrus kamali Moursi (Hymenoptera: Encyrtidae) and its impact on fecundity, progeny production and sex ratio. Biocontrol Science and Technology, 10(3), 239-244. https://doi.org/10.1080/09583150050044510

Sagarra, L. A., Peterkin, D. D., Vincent, C., \& Stewart, R. K. (2000b). Immune response of the hibiscus mealybug, Maconellicoccus hirsutus Green (Homoptera: Pseudococcidae), to oviposition of the parasitoid Anagyrus kamali Moursi (Hymenoptera: Encyrtidae). Journal of Insect Physiology, 46(5), 647-653. https://doi.org/10.1016/S0022-1910(99)00152-3

Sánchez-García, J. A., Coronado-Blanco, J. M., Ruíz-Cancino, E., Myartseva, S. N., Martínez-Martínez, L., \& Jarquín-López, R. (2016). Chalcidoidea (Hymenoptera) y otras avispas parasíticas del estado de Oaxaca, México. Entomología Mexicana, 3, 850-854.

Serrano, M. S., \& Lapointe, S. L. (2002). Evaluation of host plants and a meridic diet for rearing Maconellicoccus hirsutus (Hemiptera: Pseudococcidae) and its parasitoid Anagyrus kamali (Hymenoptera: Encyrtidae). Florida Entomologist, 85(3), 417-425. https://doi.org/10.1653/0015-4040(2002)085[0417:EO HPAA]2.0.CO;2

Schauff, M. E., La Salle, J., \& Coote, L. D. (1997). Eulophidae. In G. A. P. Gibson, J. T. Huber, \& J. B. Woolley (Eds.), Annotated Keys of the Genera of Neartic Chalcidoidea (Hymenoptera) (pp. 325-429). NRC Research Press, Ottawa, Ontario, Canada.

Trjapitzin, V. A., Bennett, F. D., Ruíz-Cancino, E., \& Coronado-Blanco, J. M. (2004). Annotated Check-list of encyrtids (Hymenoptera: Chalcidoidea: Encyrtidae) of Central America, the West Indies and Bermuda ( $\mathrm{p}$. 208, Universidad Autónoma de Tamualipas, Mexico).

Triapitsyn, S. V., Aguirre, M. B., Logarzo, G. A., \& Dal Molin, A. (2014). Taxonomic notes on primary and secondary parasitoids (Hymenoptera: Encyrtidae and Signiphoridae) of Hypogeococcus spp. (Hemiptera: Pseudococcidae) in Argentina. Acta Zoológica Lilloana, 58(2), 171-186.

Williams, D. J. (1986). The identity and distribution of the genus Maconellicoccus Ezzat (Hemiptera: Pseudococcidae) in Africa. Bulletin of Entomological Research, 76(2), 351-357. https://doi.org/10.1017/ S0007485300014814

Woolley, J. B. (1988). Phylogeny and classification of the Signiphoridae (Hymenoptera: Chalcidoidea). Systematic Entomology, 13(4), 465-501. https://doi.org/10.1111/j.1365-3113.1988.tb00256.x 
Appendix

Anagyrus kamali

Material studied. (602-A) BRASIL. SÃO PAULO: Jaboticabal $\left(21^{\circ} 15^{\prime} 29.17^{\prime \prime}\right.$ S, 48 $18^{\prime} 53.25^{\prime \prime}$ W), 3 o , 07.ix.2016, Ex: Maconellicoccus hirsutus on Hibiscus sp., A.L.B.G. Peronti col., M.A. Siqueira det.

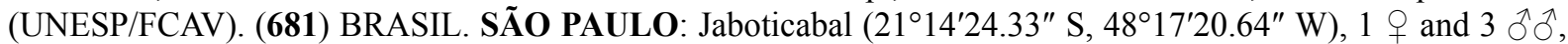
11.i.2017, Ex: Maconellicoccus hirsutus on Hibiscus sp., M.A. Siqueira col., M.A. Siqueira det. (UNESP/FCAV).

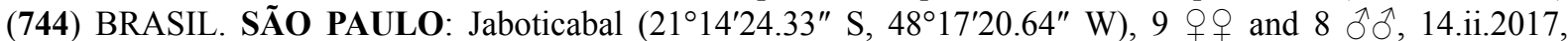
Maconellicoccus hirsutus on Hibiscus sp., M.A. Siqueira col., M.A. Siqueira det. (UNESP/FCAV). (747)

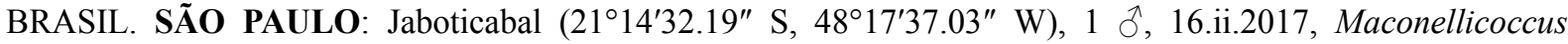
hirsutus on Hibiscus sp., M.A. Siqueira col., M.A. Siqueira det. (UNESP/FCAV). (770-A) BRASIL. SÃO PAULO: Jaboticabal $\left(21^{\circ} 15^{\prime} 29.17^{\prime \prime} \mathrm{S}, 48^{\circ} 18^{\prime} 53.25^{\prime \prime} \mathrm{W}\right), 3$ 우 and $19 \mathrm{o}^{\widehat{ }} \mathrm{o}^{\circ}$, 13.iii.2017, Ex: Maconellicoccus hirsutus on Hibiscus sp., J.G. Alexandrino col., M.A. Siqueira det. (UNESP/FCAV). (781-A) BRASIL. SÃO

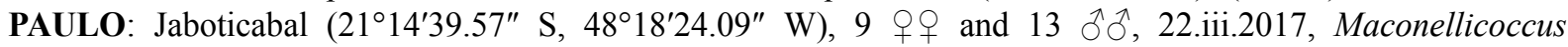
hirsutus on Hibiscus sp., M.A. Siqueira col., M.A. Siqueira det. (UNESP/FCAV). (788) BRASIL. SÃO PAULO:

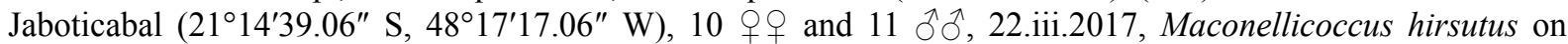
Hibiscus sp., A.L.B.G. Peronti col., M.A. Siqueira det. (UNESP/FCAV). (811-B) BRASIL. SÃO PAULO:

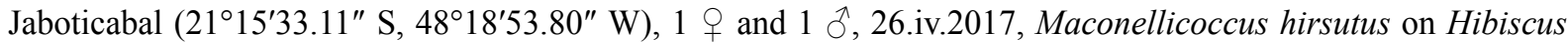
sp., A.L.B.G. Peronti col., M.A. Siqueira det. (UNESP/FCAV). (874-B) BRASIL. SÃO PAULO: Jales

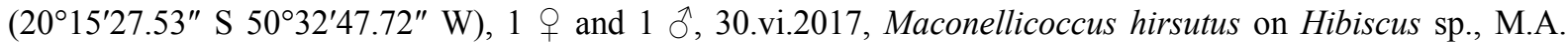
Siqueira, M.A. Siqueira det. (UNESP/FCAV).

\section{Anagyrus sp. aff. mirtesae}

Material studied. (874-A) BRASIL. SÃO PAULO: Jales $\left(20^{\circ} 15^{\prime} 27.53^{\prime \prime}\right.$ S 50 $\left.32^{\prime} 47.72^{\prime \prime} \mathrm{W}\right), 2$ 우 and $10^{\lambda}$, 30.vi.2017, Ex: Maconellicoccus hirsutus on Hibiscus sp., M.A. Siqueira col., M.A. Siqueira det. (UNESP/FCAV).

\section{Anagyrus sp.}

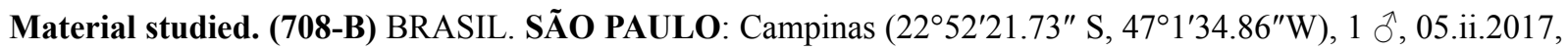
Ex: Maconellicoccus hirsutus on Hibiscus sp., M.A. Siqueira col., M.A. Siqueira det. (UNESP/FCAV). Material estudado. (770-B) BRASIL. SÃO PAULO: Jaboticabal (21 ${ }^{\circ} 15^{\prime} 29.17^{\prime \prime}$ S, 48 $\left.18^{\circ} 53.25^{\prime \prime} \mathrm{W}\right), 2$ ô, 13.iii.2017, Ex: Maconellicoccus hirsutus on Hibiscus sp., J.G. Alexandrino col., M.A. Siqueira det. (UNESP/FCAV). (781-D)

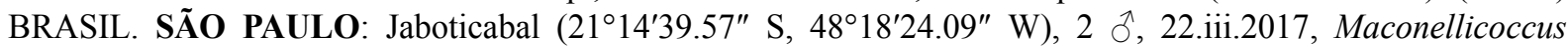
hirsutus on Hibiscus sp., M.A. Siqueira col., M.A. Siqueira det. (UNESP/FCAV).

\section{Bothriocraera bicolor}

Material studied. (602-B) BRASIL. SÃO PAULO: Jaboticabal $\left(21^{\circ} 15^{\prime} 29.17^{\prime \prime}\right.$ S, 48 $48^{\circ} 18^{\prime} 53.25^{\prime \prime}$ W), 5 우, 07.ix.2016, Ex: Maconellicoccus hirsutus on Hibiscus sp., A.L.B.G. Peronti col., M.A. Siqueira det. (UNESP/FCAV).

\section{Cheiloneurus sp.}

Material studied. (681-C) BRASIL. SÃO PAULO: Jaboticabal $\left(21^{\circ} 14^{\prime} 24.33^{\prime \prime}\right.$ S, 48 $17^{\prime} 20.64^{\prime \prime}$ W), 1 \%, 11.i.2017, Ex: Maconellicoccus hirsutus on Hibiscus sp., M.A. Siqueira col., M.A. Siqueira det. (UNESP/FCAV).

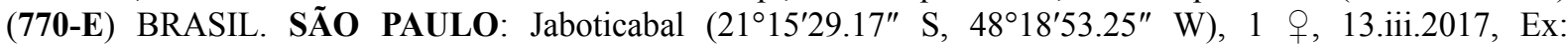
Maconellicoccus hirsutus on Hibiscus sp., J.G. Alexandrino col., M.A. Siqueira det. (UNESP/FCAV).

\section{Gyranusoidea deione}

Material studied. (602-E) BRASIL. SÃO PAULO: Jaboticabal $\left(21^{\circ} 15^{\prime} 29.17^{\prime \prime}\right.$ S, 48 $\left.18^{\circ} 53.25^{\prime \prime} \mathrm{W}\right), 2$ 우, 07.ix.2016, Ex: Maconellicoccus hirsutus on Hibiscus sp., A.L.B.G. Peronti col., M.A. Siqueira det.

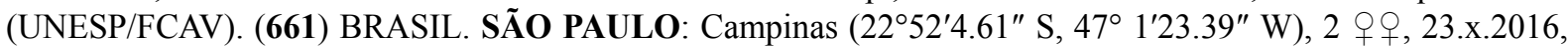
Ex: Maconellicoccus hirsutus on Hibiscus sp., M.A. Siqueira col., M.A. Siqueira det. (UNESP/FCAV). (681-D)

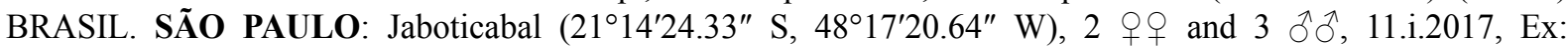
Maconellicoccus hirsutus on Hibiscus sp., M.A. Siqueira col., M.A. Siqueira det. (UNESP/FCAV). (708)

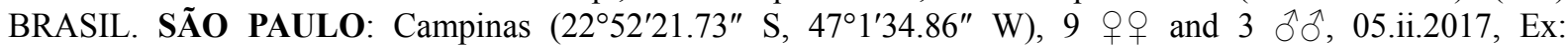
Maconellicoccus hirsutus on Hibiscus sp., M.A. Siqueira col., M.A. Siqueira det. (UNESP/FCAV). (738) BRASIL. SÃO PAULO: Jaboticabal $\left(21^{\circ} 14^{\prime} 24.33^{\prime \prime}\right.$ S, 48 $\left.17^{\prime} 20.64^{\prime \prime} \mathrm{W}\right), 3$ 우 0 and $1 \hat{o}^{\lambda}$, 14.ii.2017, Maconellicoccus hirsutus on Hibiscus sp., M.A. Siqueira col., M.A. Siqueira det. (UNESP/FCAV). (781-B)

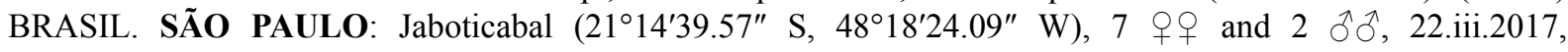


Maconellicoccus hirsutus on Hibiscus sp., M.A. Siqueira col., M.A. Siqueira det. (UNESP/FCAV). (811-A)

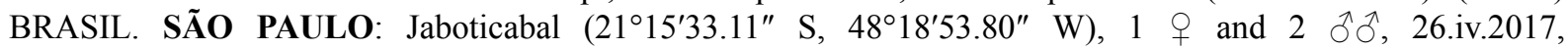
Maconellicoccus hirsutus on Hibiscus sp., M.A. Siqueira col., M.A. Siqueira det. (UNESP/FCAV).

\section{Prochiloneurus sp.}

Material studied. (781-C) BRASIL. SÃO PAULO: Jaboticabal $\left(21^{\circ} 14^{\prime} 39.57^{\prime \prime}\right.$ S, 48 $18^{\prime} 24.09^{\prime \prime}$ W), 1 \% 22.iii.2017, Maconellicoccus hirsutus on Hibiscus sp., M.A. Siqueira col., M.A. Siqueira det. (UNESP/FCAV).

Aprostocetus sp.

Material studied. (770-C) BRASIL. SÃO PAULO: Jaboticabal $\left(21^{\circ} 15^{\prime} 29.17^{\prime \prime}\right.$ S, 48 $8^{\circ} 18^{\prime} 53.25^{\prime \prime}$ W), 1 q, 13.iii.2017, Ex: Maconellicoccus hirsutus on Hibiscus sp., J.G. Alexandrino col., M.A. Siqueira det. (UNESP/FCAV).

\section{Chartocerus sp.}

Material studied. (770-D) BRASIL. SÃO PAULO: Jaboticabal $\left(21^{\circ} 15^{\prime} 29.17^{\prime \prime}\right.$ S, 48 $8^{\circ} 18^{\prime} 53.25^{\prime \prime}$ W), 1 q, 13.iii.2017, Ex: Maconellicoccus hirsutus on Hibiscus sp., J.G. Alexandrino col., M.A. Siqueira det. (UNESP/FCAV).

\section{Copyrights}

Copyright for this article is retained by the author(s), with first publication rights granted to the journal.

This is an open-access article distributed under the terms and conditions of the Creative Commons Attribution license (http://creativecommons.org/licenses/by/4.0/). 